Kwartalnik Młodych Muzykologów UJ

no. 47 (4/2020), 103-137

DOI 10.4467/23537094KMMUJ.20.044.13917

www.ejournals.eu/kmmuj

iD https://orcid.org/oooo-0oo2-5646-6622

\title{
Karol Rzepecki
}

The John Paul II Catholic University of Lublin

\section{The Reception of Józef Wieniawski's Works in the Light of Nineteenth-Century Writings - A Survey of Sources}

\section{Abstract}

The output of Polish composers active at the turn of the twentieth century has largely been forgotten and is still waiting to be properly researched nowadays. Józef Wieniawski and his oeuvre, which once used to attract the attention of both Polish and foreign critics, is a case in point. This article seeks to provide a synthetic study of this subject on the basis of $19^{\text {th }}$-century literature.

\section{Keywords}

Józef Wieniawski, Henryk Wieniawski, Polish music 
Józef Wieniawski (1837-1912), one of Poland's most eminent composers active in the second half of the nineteenth century, has now largely fallen into oblivion. After the modest monograph by Léon Delcroix, ${ }^{1}$ published still in the artist's lifetime, this brother of the famous violinist Henryk Wieniawski, born in Lublin, has not received any synthetic biographical profile (I have therefore attempted to present one in this paper), nor has any work been written dedicated to the reception of Józef's musical output. I have therefore studied the major press titles published in such cultural hubs as Warsaw, Berlin, Paris, and Brussels, in which the pianist was active. These include dailies, weeklies, and specialised periodicals. It is my hope that the present paper will provide a starting point for further research concerning that composer's life and work.

Articles about, or brief mentions of, Józef Wieniawski's individual works, appeared regularly in both Polish and foreign press. Titles published in the territory of partitioned Poland included Bluszcz, Echo Muzyczne i Teatralne [Music and Theatre Review], Echo Muzyczne, Teatralne i Artystyczne [Music, Theatre and Art Review], Gazeta Lwowska [Lviv Gazette], Kłosy, Kurier Warszawski [The Warsaw Courier], Ruch Muzyczny [Music Life], and Tygodnik Ilustrowany [The Illustrated Weekly]. Abroad, such information can be found in Caecilia. Algemeen Muzikaal Tijdschrift van Nederland, L'Art Moderne, L'Europe, Le Figaro, Le Guide Musical, Le Ménestrel, Morning Post, Musikästhetische Betrachtungen, Musikalisches Centralblatt, Musikalisches Wochenblatt, Revue Gazette Musicale de Paris, Revue Musicale Sainte Cécile, Signale für die Musikalische Welt, and The Illustrated London News. In my quotations, I preserve the original spelling and style, even in cases when they may be considered incorrect today.

The earliest such a commentary, concerning Grand duo polonais Op. 5, was printed in July $1855,{ }^{2}$ as many as three years after the composition of that piece. The anonymous author lists in detail the successive sections of the composition, written jointly by the Wieniawski brothers:

L. Delcroix, Joseph Wieniawski (1908).

2 Ker, 'Grand Duo Polonais pour Violon et Piano concertant compose par les freres Henri et Joseph Wieniawski', Signale für die Musikalische Welt, 31 (1855), 241-242. 
The duo starts in $\mathrm{G}$ major. After many measures of introduction, there comes a Cossack dance in $\mathrm{E}$ minor, then the main theme, $\mathrm{Ma}$ ciek, in $\mathrm{G}$ major, followed by Wieniawski's variations and cadenzas. ${ }^{3}$

The author praises the work, saying: 'It was like fireworks with ten million sparks and fine flares'. ${ }^{4}$

The Grand duo, one of Józef Wieniawski's first attempts at music composition, was well received by the German critic, who in a later part of his text refers to the patriotic overtones present in some passages and concludes: 'How hot the Polish blood! How beautiful the dance! Let's join the line, then.' In later years, reviews of Wieniawski's music were not always so enthusiastic. We should, however, draw a clear line between the opinions of Polish and foreign critics, as I shall demonstrate below.

The first such a review, which appeared in Revue Gazette Musicale de Paris in May 1857, concerned a concert held on 25 February at Amsterdam's Société Félix Meritis, where

Mr Wieniawski played the first movement of his Piano Concerto in $G$ minor, which he recently composed in Berlin. The orchestra was conducted by Henry Litolff, while [the composer's] brother Henryk was the concertmaster. ${ }^{6}$

Several weeks later, the Polish magazine Ruch Muzyczny wrote about the Polonaise in C major Op. 13 that 'one needs to look hard in this composition to develop a taste for it'? On the basis of the critic's later comments, we may conjecture that this opinion resulted from the Lublin-born composer still gradually learning the composition technique. Nevertheless, later on we also find this praise: 'Care and the intention to strive after better music writing are evident. The overall effect is pleasant.' ${ }^{8}$ Less than a year later, in February 1858, the same magazine printed a longer note dedicated to the pianist, listing his major successes so far, but also assessing his composition technique. The already mentioned Polonaise was then one of the most recently

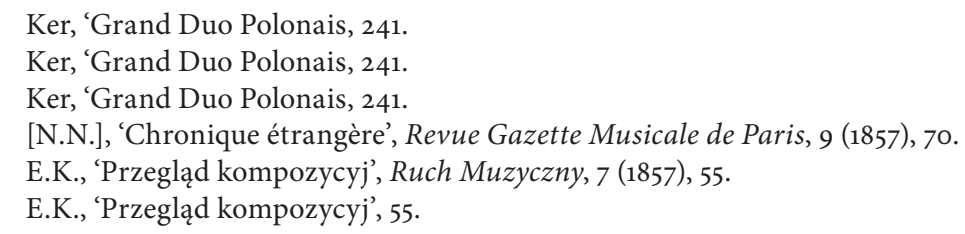


completed pieces by Wieniawski. From the text we learn that 'among the thirteen that have been printed to date, there are some that bring the composer honour both in terms of dimensions and imagination.'9 The author is more attracted, however, to the contents of the unpublished manuscripts, which, he writes, are 'proof of the most beautiful determination, not to mention their poetic spirit. ${ }^{30}$ Several weeks later, in an account of a concert held in early March 1858, the author assesses the pianist's interpretation of Felix Mendelssohn-Bartholdy's Piano Concerto in $G$ minor Op. 25 and dedicates a separate paragraph to Wieniawski's own works. Of the latter, the concert programme included 'a romance with variations, a concert waltz, and an elegiac adagio followed by a rondo of cheerful character. ${ }^{11}$ These works are assessed as follows:

There is a spring in all of them, used with moderation, much elegance and imagination careful about disclosing its treasures, but very fine. These compositions definitely stand out among others owing to their thought, not overly original, but its originality is particularly audible in the passages, fresh and full of splendour. It is a pity Mr W. has not shown us any of his pieces with orchestral accompaniment, or the purely orchestral ones. ${ }^{12}$

The works in question are Wieniawski's Valse de concert Op. 3, Fantaisie et variations de concert pour piano sur des motifs de la 'Somnambula' de Bellini Op. 6, and Romance-Étude Op.10, the fruit of the composer's studies with Pierre Zimmermann at the Conservatoire de Paris. The composer seems to have responded to the regret expressed at the end of the above-quoted statement already in the same month, when during another concert he presented, for the first time in Warsaw, a little taste of his symphonic music. On 24 March 1858 at the Warsaw Merchants' Club, Wieniawski played Ludwig van Beethoven's Piano Concerto in C minor Op. 37 (a work, as we learn, 'almost completely unknown here ${ }^{1_{13}}$ at that time) with his own cadenza. Though written around 1857 , this cadenza was only printed in London twenty years

\footnotetext{
[N.N.], 'Józef Wieniawski', Ruch Muzyczny, 7 (1858), 51.

[N.N.], 'Józef Wieniawski', 51.

[N.N.], 'Koncert Pana Józefa Wieniawskiego', Ruch Muzyczny, 10 (1858), 77.

[N.N.], 'Koncert Pana Józefa Wieniawskiego', 78.

${ }_{13} \quad$ [N.N.], 'Koncert Pana Józefa Wieniawskiego w Resursie Kupieckiej', Ruch Muzyczny, 13 (1858), 99.
} 
later; on the title page of that edition, we find the date of its performance during a concert at London Philharmonic Society, 9 July $1877^{14}$ The cadenza was assessed as follows:

In this Cadenza, $\mathrm{Mr} \mathrm{W}$. summarised all the Allegro from the said concerto, taking the theme of the first tutti as his framework and weaving into it other major features taken from the same movement. He wove all this into a whole with its own caesuras, its own light and hues, representing as if in miniature what Beethoven developed at length. This alone tells us much about Mr W.'s studies on the concerto and explains his splendid presentation of the whole. ${ }^{15}$

Under the composer's baton, the audience also heard his now lost Overture in D major, which attracted no less interest:

As a composer, $\mathrm{Mr} \mathrm{W}$. mainly stirred up interest with his concert Overture (in D) for orchestra. It is characterised by the ease and simplicity of ideas, small dimensions, and, so to speak, fragmentary nature. Not very extensive, it nevertheless presents many details, among which careful instrumentation is what mainly attracts the listener's attention. We will consider it as an orchestral study rather than the fruit of inspiration; as a plaything, reflecting the composer's liking for such models, and not as an independent product meant to demonstrate the artist's skills as a composer. ${ }^{16}$

Unlike the Cadenza, the Overture, one of Wieniawski's first symphonic works, met with condescending opinions, as later reviews in Ruch Muzyczny aptly demonstrate.

Wieniawski continued to present his symphonic works during the third and last matinee, when he performed his Piano Concerto in $G$ minor Op. 20. This tripartite composition, following the classical conventions, was thus assessed by an anonymous music critic:

The main ideas (themes) of each of the three concerto movements (Allegro moderato, Andante, Allegro molto vivace) correspond well to the dimensions of the forms they are meant to fill in; this is their technical strength. ${ }^{17}$

14 J. Wieniawski, Cadenza pour le 3me Concerto pour le Piano de Beethoven (1878).

15 [N.N.], 'Koncert Pana Józefa Wieniawskiego w Resursie Kupieckiej', 99.

16 [N.N.], 'Koncert Pana Józefa Wieniawskiego w Resursie Kupieckiej', 100.

${ }_{17} \quad$ [N.N.], 'Trzeci koncert p. Józefa Wieniawskiego', Ruch Muzyczny, 15 (1858), 114. 
At the same time, the reviewer emphasised the sonic qualities of that music. In his presentation of the individual movements, he commented:

Their poetic significance is no less important. While listening to their noble development and appreciating the continual interest they provide, we must admit from the start that they are far from trivial as a subject for discussion. ${ }^{18}$

Summing up this part of his commentary, he added:

We should admit, however, that as in the development we can always find nobility, gravity and force, even great power at points, so in the character of the material there is dignity and resolution. This is most strongly evident in the third movement, which makes the Finale most original. It is a swift and vigorous conclusion to what started pompously in the first Allegro and received a sensitive response in the Andante. ${ }^{19}$

The orchestral part was also submitted to analysis. The instrumentation is described in highly positive terms as 'an interplay of colours and light, resulting from routine procedures just as much as from ideas, if not more. ${ }^{20}$ The author discerns some original elements and products of the composer's own invention in this Concerto, but, in his opinion, they do not go beyond the conventions of the day:

In Mr Wieniawski's work, so carefully finished off, there is also evidence of care for this element, and for clarity in the piano figures. Though not strikingly original, they are far from commonplace and do not detract from the composer's autonomy. ${ }^{21}$

This article provides us with the first in-depth analysis of the young pianist's music. The Piano Concerto in G minor was presented to the Warsaw audience for the second time on 10 December 1858. This time, Wieniawski was described as a young artist who consistently follows the path that he set for himself in order to achieve the goal of winning recognition among audiences and in the artistic circles. With this work,

$18 \quad$ [N.N.], 'Trzeci koncert...', 114.

$19 \quad$ [N.N.], 'Trzeci koncert...', 114.

${ }_{20} \quad$ [N.N.], 'Trzeci koncert...', 114.

${ }_{21} \quad$ [N.N.], 'Trzeci koncert...', 115. 
the author claims, the artist joins the narrow elite of artists composing large-scale forms. He describes the Concerto as

a stately work in its kind, with beautiful ideas and well-thought-out development, of exquisite dimensions, which gives the composer a place among masters known as the classical school, mainly because they guard the form that has been lovingly shaped, intellectually conceived, and established. ${ }^{22}$

The reviewer compares listening to the Concerto to contemplating a painting, which 'delights and benefits the spirit. ${ }^{23}$ In the early period of his activity as a composer, Wieniawski was perceived by Polish critics as an artist working within the limits of the then dominant conventions. The composition discussed here was one of the first piano concertos written by a Polish composer after 1850. This aspect of the work was mentioned in 1859 by Józef Doroszenko (pen name of Marceli Jasiński), who also praised the orchestration, but criticised the overly modest place of the solo instrument in this work:

The instrumentation is beautiful and well thought-out. The orchestra is not the mere 'rest' affirming the single one. On the contrary, the solo piano and the others invited to play in the score form a company animated by one spirit and talking about one and the same subject. We might even blame the piano for being too modest and saying less than its rightful part. All the same, we respect the author's will and sense, and welcome him with joy. ${ }^{24}$

This is the way Marceli Jasiński (1837-1867) presented Wieniawski’s technique, writing from the perspective of a fellow-composer.

Another mention of Wieniawski's early output, this time in the foreign press (Revue et Gazette Musicale de Paris) concerns either his Valse de concert Op. 3 or Valse de Salon Op. 7: 'Girod will publish Józef Wieniawski's famous waltz, which won great success at the latest concert, drawing the audience's applause and enthusiasm. ${ }^{25}$ Wieniawski did not compose any other waltz before 1860 . The edition mentioned

${ }_{22}$ [N.N.], 'Koncert pp. J. Wieniawskiego, Al. Reicharda i Ad. Hermana', Ruch Muzyczny, 51 (1858), 406.

${ }_{23} \quad$ [N.N.], 'Koncert pp. J. Wieniawskiego, Al. Reicharda i Ad. Hermana', 407.

24 J. Doroszenko, 'Wieści z kijowskich koncertów', Ruch Muzyczny, 12 (1859), 105.

25 [N.N.], 'Chronique étrangère', Revue Gazette Musicale de Paris, 19 (1860), 169. 
in this text never materialised, though, and the Parisian publisher (operating in 1855-1919) did not print any such composition. In the same period, in Ruch Muzyczny's column 'Przegląd kompozycyj' ['Reviews of New Works]', an anonymous author commented on two other items:

Józef Wieniawski’s Souvenir de Lublin Op. 12

Wieniawski's harmony is usually refined but not overdone; the figurations - very interesting if not innovative; his piano writing skill leaves nothing to be desired. The theme - truly exquisite, so there must also be variations. We remember how the composer played them himself not long ago, and so they need no further recommendation. One needs to be warned, however, that the first variation is rather difficult though it may not seem so at first glance, while the second, though apparently more formidable, is relatively easy.

Józef Wieniawski’s Impromptu Op. 19

It has all the qualities of a carefully composed work with a well-developed style and artistic idea. While the above-mentioned piece is a lovingly wrought gem, this one is a fully-fledged music work and a product of genuine musicality. Do not let such a statement put you off; the composer's technique is too good to lead the performers astray. ${ }^{26}$

This was the first in-depth analysis of these two works, of which Impromptu Op. 19 had not yet been printed. Several weeks later, a Ruch Muzyczny correspondent informed about a Paris performance of the above-mentioned Overture in D major, in which he 'praises the ideas and their execution but calls for a more compact treatment. ${ }^{27} \mathrm{On}$ 26 April 186o, Józef Wieniawski presented himself as a pianist and composer at the Parisian Salle Herz, to which, as we hear, he 'returned after ten years spent abroad. ${ }^{28} \mathrm{He}$ appeared there also as a conductor, 'performing his $G$ minor Concerto, with great success. ${ }^{29}$ Wieniawski visited Paris once more at the end of the same year, giving a cycle of three concerts at Salle Pleyel. The local composer and music critic Adolph Botte (1823-1896) carefully kept trace of these performances. In his view, 'the Impromptu and Pensée fugitive showed the author in his

26 [N.N.], 'Przegląd Muzyczny', Ruch Muzyczny, 19 (1860), 315.

${ }_{27} \quad$ [N.N.], 'Przegląd Muzyczny', 320.

28 [N.N.], 'Soirées et concerts', Le Ménestrel, 27 (1860), 159.

29 [N.N.], 'Soirées et concerts', Le Ménestrel, 28 (1860), 167. 
double capacity: his talent as a pianist and technique as a composer. ${ }^{30}$ On 27 December Wieniawski performed at the Lycée Louis-le-Grand, playing his 'Souvenir de Lublin and Valse de concert, which met with the highest acclaim.. ${ }^{31}$ The author believes that 'Mr Wieniawski turns out to occupy the middle ground between the classics and composers fond of present-day musical forms. ${ }^{32}$ By the latter he probably means the variation form. This opinion was by no means isolated. During the last of the three concerts in the cycle, held on 19 February 1861 at Salle Pleyel, the artist played his Polonaise in A-flat major Op. 21, which, according to a Ruch Muzyczny reviewer, is 'a very difficult and truly excellent piece, highly melodious and well-designed despite some lengthy fragments. ${ }^{33}$ This was the first review of the composition, and it appeared before the piece came out under the imprint of the Russian publisher Alexander Gutheil in 1862. Wieniawski spent September 1861 in Wiesbaden. From that period, we have the first mention of his collaboration with Nikolai Rubinstein (1835-1881): 'Józef Wieniawski has been composing diligently, and from Nikolas Rubinstein we heard performances of many of his collected works. ${ }^{3} 4$

With the passage of time, along with opinions concerning individual works, information began to appear (as in the case of the waltz) concerning their publication. In early April 1863 Wieniawski's Impromptu por Piano Op. 19 was listed among 'this week's new scores. ${ }^{35}$ This time, the information is true since the piece was printed by Friedrich Kirstner in Leipzig. In October the same publisher printed the collection of Huit Mazurkas pour Piano par Wieniawski Op. 23, which a reviewer describes as 'varied and creative' works, with 'tendencies characteristic of our nation [...] and not very difficult, therefore suitable for social occasions. ${ }^{36}$ This cycle of eight pieces printed in two booklets was one of the first fruits of a new stage in the composer's life, related to his move to Moscow, which was officially announced in January $1865.3^{37}$

\footnotetext{
30 A. Botte, 'Koncert Józefa Wieniawskiego', Revue Gazette Musicale de Paris, 52 (1860), 440.

${ }^{31} \quad$ [N.N.], 'Nouvelles', Revue Gazette Musicale de Paris, 53 (1860), 449.

32 [N.N.], 'Nouvelles', Revue Gazette Musicale de Paris, 53 (1860), 449.

33 [N.N.], 'Gazeta Muzyczna', Ruch Muzyczny, 10 (1861), 151.

34 [N.N.], 'Dur und Moll', Signale für die Musikalische Welt, 38 (1861), 523.

35 [N.N.], 'Dur und Moll', Signale für die Musikalische Welt, 18 (1863), 291.

36 [N.N.], 'Dur und Moll', Signale für die Musikalische Welt, 42 (1863), 681.

37 [N.N.], 'Dur und Moll', Signale für die Musikalische Welt, 4 (1865), 58.
} 
A longer article dedicated to Wieniawski's music was printed in December 1868 in Bluszcz (illustrated women's weekly). By that time Józef had won recognition not only as a composer but also a teacher (professor of Moscow Conservatory and head of his own music school in that city). A critic lavished praise on both his output as a composer and his piano technique: 'Like very few others, Mr Wieniawski can bring one element to the fore and place another in the background so that they mutually do not drown out each other. ${ }^{38}$ He further seeks analogies between Wieniawski's music and paintings, though no specific composition is mentioned in this context. Another text important for the study of the assessment of the composer's output by his contemporaries was printed in January 1869 in Tygodnik Ilustrowany. Its author, Jan Kleczyński, Wieniawski's collaborator of the same age as the pianist (1837-1895), diametrically changed his opinions about his colleague's music and piano technique over the years. In the first part of his official statement concerning the Piano Concerto in G minor, he notes that 'the finale is full of life, ${ }^{39}$ praises the logic and consistence observable in Wieniawski's music, and adds: 'everything is thought out in advance; rarely does the composer act under the spur of imagination. ${ }^{40}$ In March 1871, the same critic commented: 'Mr Wieniawski superbly played Chopin's Etude and also very beautifully the Impromp$t u$ and the Nocturne, but his own Polonaise failed to make the expected impression on us. ${ }^{21} \mathrm{He}$ adds, however, that

another piece by Mr W., a Romance sung by Miss H. Troschel, was very much to our liking. We only have one little remark for the author, namely, that in the French phrase comme nous there are three syllables rather than two. ${ }^{42}$

This shows that Wieniawski's output was subjected to thorough analyses by one of Warsaw's then most influential music critics. Soon afterwards Kleczyński wrote in a similar vein about Wieniawski's $C a$ denza for Ludwig van Beethoven's Piano Concerto in C minor, Op. 37 a. The critic observed:

${ }^{38}$ J. Kleczyński, 'Ruch Muzyczny', Bluszcz, 51 (1868), 333.

39 J. Kleczyński, 'Ze świata muzycznego', Tygodnik Ilustrowany, 57 (1869), 50.

40 J. Kleczyński, 'Ze świata muzycznego', 50.

${ }^{41}$ J. Kleczyński, 'Ruch Muzyczny', Bluszcz, 13 (1871), 103.

${ }^{42}$ J. Kleczyński, 'Ruch Muzyczny', Bluszcz, 13 (1871), 103. 
The Cadenza for the first movement composed by Mr W. is very beautiful. Its ending may perhaps be viewed as somewhat too modern, though this is justified by the need to create a splendid effect at the end. ${ }^{43}$

This composition by Beethoven was one of the most frequently performed concertos in Wieniawski's repertoire throughout his career. After that review, there is a longer period of silence in both local and foreign press concerning Wieniawski's work as a composer.

1875 marked the beginning of a new stage in Wieniawski's life. For three successive years, he was the artistic director of Warsaw Music Society (WTM), responsible for organising the cyclic concerts. With time, he began to use them as an opportunity to present his own works, as Kleczyński notes in his articles. During one of such concerts, on 6 April 1876, in the solo part of the programme, apart from pieces by Chopin and Beethoven, Wieniawski played his own music: Deuxieme Tarantelle Op. 35 and Polonaise pour le Piano Op. 21. The critic wrote about these compositions:

[O]f works for solo piano, one should not forget to mention two original pieces by $\mathrm{Mr}$ Wieniawski: his second Tarantelle, and especially his Polonaise (in A-flat major), a work of much merit. ${ }^{44}$

In the following season, during a concert held on 20 September 1876, Wieniawski presented another of his compositions. On 5 October Kurier Warszawski printed a long account of the seventy-second concert from Warsaw Music Society's cycle. This text contains the first mention of a performance of String Quartet in A minor Op. 32, which opened the concert programme: 'Mr Wieniawski took complete possession of the listeners' hearts. ${ }^{45}$ We may probably consider this to have been the Quartet's premiere. In the solo part of the programme, Wieniawski played his Mazurka in A major Op. 23 No. 1 (dedicated to Maria Sułkowska). ${ }^{46}$ which 'only the composer himself could perform like this. ${ }^{27}$ This event, then, provided another opportunity for the

43 J. Kleczyński, 'Ruch Muzyczny', Bluszcz, 18 (1871), 142.

44 J. Kleczyński, 'Ruch Muzyczny', Bluszcz, 16 (1876), 124.

45 [N.N.], Kurier Warszawski, 219 (1876), 2.

${ }_{46}$ Its manuscript is kept at the Library of Warsaw Music Society (hereinafter as BWTM), shelf mark...

47 [N.N.], Kurier Warszawski, 207 (1876), 1. 
inhabitants of Warsaw to become acquainted with the works of one of that period's leading composers. A piano transcript of the String Quartet has been preserved to our day in the library of Warsaw Music Society. ${ }^{48}$ The work was published in 1882.

It should be mentioned in this context that Józef Wieniawski was the first WTM director to have undertaken to establish both an orchestra and a choir in accordance with the Society's statute. In September 1877, Kurier Warszawski announced that Wieniawski's Semiramide would be the highlight of the Wednesday concert held on 3 October:

Next Wednesday at our Music Society, this season's second evening concert will be held, largely dedicated to multi-part vocal works. One of those to be performed is a new composition for voices by Mr Józef Wieniawski, Semiramide.49

The then presented version of this work has not survived to our day. The work received the following review:

Is this meant to be a number from an opera or a symphonic poem, or simply a choral piece whose title could easily be exchanged for another one? We must admit we have been unable to discover any links between the work's content and its title. Our search was made the more difficult by the organ accompaniment, whose presence in the context of Assyrian choruses is hard to explain. Apart from its Oriental intentions, Mr Wieniawski's composition, as a choral piece, does not stand out for any profound thought, and makes little impression..$^{\circ}$

Semiramide is Wieniawski's first and only choral work. It draws on the story of the Assyrian queen Semiramide. The criticism may have been partly due to the subject matter, since Henryk Jarecki's psalm for the same performing forces, sung during the same concert, was favourably received by the critic. The topic chosen by Wieniawski was exceptional in the vocal-instrumental output of Polish composers.

The second half of 1878 brought changes in the composer's life. He resigned from the post of WTM director, motivating his decision with

$48 \quad$ BWTM, shelf mark R 3448.

49 [N.N.], Kurier Warszawski, 211 (1877), 2.

5० [N.N.], Kurier Warszawski, 218 (1877), 1. 
health reasons, and did not stand for another term. He thus had more time for his work as a composer, teacher, and concert pianist, and remained independent of any institutions until the end of his life. In December of the same year, the press informed that 'Józef Wieniawski is becoming more active as a composer. ${ }^{5_{1} 1}$ Four of his pieces came out in print nearly simultaneously in London, Paris, and Leipzig: Sonate pour Piano et Violoncelle Op. 26, Cadenza pour le 3me Concert pour le Piano de Beethoven Op. 37, Deuxieme Impromptu Op. 34, and Deuxieme Étude de Concert Op. 36. All of them gradually became staples of the pianist's repertoire.

On 17 January 1881, Wieniawski played in Lviv's City Hall for the local audience, presenting, among others, his own music. The reviewer's attention was attracted by Polonaise in B major Op. 27, published several weeks earlier by Christian Kahnt in Leipzig:

From among own compositions by the pianist, who received an ovation both during and after the concert from the numerously assembled audience, the one I particularly liked was the beautiful (third) polonaise filled with a truly refined atmosphere..$^{52}$

Kleczyński's assessment of the same piece was quite different, as has been said above.

For the next several months, Wieniawski toured in Western Europe with solo and chamber music concerts. After the Lviv performance, he did not play his own works until 20 February 1882, when he inaugurated the Monday concerts at Salle Herz in Paris ${ }^{53}$ with a programme of music by Haydn, Mozart, Chopin, Liszt, as well as his own waltz: 'For the second time in Paris, Mr Wieniawski will play his Deuxieme valse de concert, worthy of perfect acclaim. ${ }^{54}$ Several days later, on 25 February, a Parisian daily informed:

Mr Józef Wieniawski's fourth concert will be given tonight at Salle Herz. The programme includes Cello Sonata Op. 26, which we will hear in the interpretation of the composer and Mr Hollman..$^{55}$

${ }_{51} \quad$ [N.N.], Kurier Warszawski, 290 (1878), 2.

52 F. Bylicki, 'Ze sceny koncertowej', Gazeta Lwowska, 13 (1881), 2.

53 [N.N.], 'Echos des theatres', Le Gaulois, 888 (1882), 4.

54 [N.N.], 'Echos des theatres', 4.

55 [N.N.], 'Revue des theatres', Le Petit Journal, 7001 (1882), 3. 
Dutch cellist Joseph Hollman was one of those who most frequently accompanied Wieniawski in performances of this piece, to the thunderous acclaim of audiences, mostly in France and Belgium. The composer played the same work at the summer residence of the van der Heyden family in Ostend, ${ }^{56}$ this time with Éduard Jacobs, graduate of the Royal Music Conservatory in Brussels, as soloist, which again 'met with a thunderous audience applause. ${ }^{57}$ In May, the Leipzig journal Musikalisches Centralblatt informed about the success of a concert cycle given by Wieniawski in Salle Erard and Salle Herz, where he also played his own music. The programme of the fourth out of ten performances featured 'Mr Wieniawski's highly attractive Sonata for piano and cello; the cello part was taken up by $\mathrm{Mr}$ J. Hollman', ${ }^{8}$ whereas 'at the next concert, the artist delighted us with his Sonata Op. 24 for piano and violin, featuring Jenő Hubay.'59 This confirms that Wieniawski scored successes abroad, including in the French capital. The dates of his later concerts are not quoted in this news item.

In late January 1883 Wieniawski focused on symphonic concerts, appearing twice (on 28 and 30 January) at Le Grand Harmonie under the baton of Joseph Martens. The programme of that latter concert included his Piano Concerto in G minor Op. $20^{60}$. In between these two, he played a chamber music concert in the same venue, where, after a performance of his Violin Sonata Op. 24 'Wieniawski the composer was applauded just as vehemently as Wieniawski the pianist. ${ }^{31}$ The composition itself (performed, as the critic notes, already for the second time in this venue) was reviewed as follows:

Written in the free and colourful style of Rubinstein i Chopin, whom this sonata in a way brings to mind, it is distinguished, from the start till the very end, by the enormous purity of its message and formal

${ }_{56}$ K. Rzepecki, 'Józef Wieniawski (1837-1912) - epoka, człowiek i dzieło. Studium historyczno-muzykologiczne', PhD dissertation (2019), 203.

$57 \quad$ [N.N.], 'Le Journée', L'Europe, 917 (1882), 1.

${ }_{58}$ [N.N.], 'Eingesandte Concert-Programme', Musikalisches Centralblatt, 18 (1882), 186.

$59 \quad$ [N.N.], 'Eingesandte Concert-Programme', Musikalisches Centralblatt, 18 (1882), 186.

60 [N.N.], 'Eingesandte Concert-Programme', Musikalisches Centralblatt, 4 (1883), 54

${ }_{61}^{6} \quad$ [N.N.], 'Concerts Wieniawski', L’Art Moderne, 5 (1883), 37. 
perfection, both of which prove the hand of a wise and experienced artist. The violin part was performed with much grace and purity by Mr Jenö Hubay, who wonderfully conveyed the poetic and dreamy aspects of this work. ${ }^{62}$

In January 1884, L'Art Moderne announced the publication of yet another work: 'The publisher Breitkopf \& Härtel has just brought out the Nocturne E minor by Mr Józef Wieniawski, which constitutes his Opus $37^{163}$. This information is followed by a brief appraisal: 'It is a well-written piece, suited to the sound of the piano. The melodic turns show an affinity to the melancholy dream pieces by Chopin. ${ }^{64}$ That latter similarity was emphasised by many authors in the years that followed.

On the last day of May 1884, the art magazine Echo Muzyczne i Teatralne printed the first part of Jan Kleczyński's article in which the critic attempted to present a biographical profile of Józef Wieniawski. Overall, the critic claims that 'as a composer W. has demonstrated a thorough knowledge of musical forms in [his] sonata for piano and violin (Op. 24), in the concerto, and the sonata with cello.65

Deeper analysis reveals Kleczyński's doubts concerning the merits of the composer's output. He criticises Wieniawski for his works being overly long: 'unnecessary extension of form makes the Violin Sonata hard to perform, however, since it lasts, as far as we can remember, about three quarters of an hour. ${ }^{66}$ Kleczyński voiced similar opinions several times more in later years, with reference to other compositions. At the same time, however, 'W.'s pieces in lighter style are incomparably more felicitous. In them, elegance, wit and charm prevail. ${ }^{6} 7$ Here the critic gives the example of Valse de concert Op. 3, which is still popular and most willingly performed by many virtuosi. ${ }^{68}$ Eight years after the review quoted earlier, Kleczyński commented on Polonaise Op. 21, which, he says, has a 'wonderful first theme, but is not riveting as a whole; as frequent in W.'s music, his later work detracts from the

${ }_{62}$ [N.N.], 'Concerts Wieniawski', 37.

${ }_{63}$ [N.N.], 'Petite chronique', L'Art Moderne, 4 (1884), 30.

${ }^{64}$ [N.N.], 'Petite chronique', L'Art Moderne, 4 (1884), 30.

65 J. Kleczyński, 'Józef Wieniawski', Echo Muzyczne i Teatralne, 36 (1884), 370.

66 Kleczyński, 'Józef Wieniawski', 370.

${ }^{67}$ Kleczyński, 'Józef Wieniawski', 370.

68 Kleczyński, 'Józef Wieniawski', 371. 
freshness of the original idea. ${ }^{69}$ The critic counts all of Wieniawski's music written before and including this polonaise among 'early compositions' ${ }^{70}$ whereas in the second group, which he refers to as 'later pieces', 'of note are the Ballade and the Valse de concert. ${ }^{71} \mathrm{He}$ must have meant the Ballade in E-flat minor Op. 31, which is the only one to be found in the catalogue compiled by Kleczyński and comprising works from Deux Idyles Op. 1 to Six piéces romantiques Op. 39. To this list, Kleczyński added a dedication and the names of publishers of the individual works. The catalogue was incomplete. The author left out the Cadenza for Beethoven's Piano Concerto No. 3 Op. 37, though it was already available in print.

In June 1884 L'Art Moderne informed: 'Mr Józef Wieniawski continues to publish his music, thus presenting the entire scope of his talent.'72 From that moment on, the press (mainly French- and German-language titles) regularly informed about his activity as a composer. In mid-August Le Guide Musical printed a note from which we learn that at the end of the month Józef Wieniawski's Six Piéces Romantiques Op. 39 came out under the Schott imprint in two booklets sold at 30 francs each. ${ }^{73}$

Mazourka de Concert Op. 41 was published soon afterwards. It was a period of intense work for Wieniawski, not only in the field of composition. As in the previous two years, he started 'a piano course, taught at his flat at 23 Rue du Pepin, which has proved indispensable for our musical education. ${ }^{34}$ The course was one of Wieniawski's reasons for compiling the piano cycle Op. 39, in which he dedicated each piece to a different female pupil. In October we learn that

as a prolific composer of versatile talent, expressing his ideas with great control and ease, Mr Józef Wieniawski has enriched the piano repertoire with a cycle of elegant and attractive works. ${ }^{75}$

The brilliance and nobility of his style was emphasised, as well as his improvising skills. The cycle's reception was not unequivocally

\footnotetext{
69 Kleczyński, 'Józef Wieniawski', 371.

7o Kleczyński, 'Józef Wieniawski', 371.

${ }_{71} \quad$ Kleczyński, 'Józef Wieniawski', 371.

72 [N.N.], 'Les peintres belges au salon', L’Art Moderne, 25 (1884), 205.

73 [N.N.], 'Nouvelles diverses', Le Guide Musical, 34-35 (1884), 232.

74 [N.N.], 'Nouvelles diverses', Le Guide Musical, 37 (1884), 243.

75 [N.N.], 'Nouvelles diverses', Le Guide Musical, 43 (1884), 349.
} 
favourable, though. 'In the Ballade,' we learn, 'which is the fourth of the romantic pieces in this collection, he comes very close to imitation, against which we wish to warn him. ${ }^{76}$ The Mazourka de Concert Op. 41, on the other hand, was described as 'an outstanding composition, bold and spirited, with a confident but carefully restrained design. ${ }^{37}$

The critic also stresses the composer's mastery of the style characteristic of the national dance forms:

In his harmony we can hear the clanking of spurs again. One may easily imagine in his swinging rhythms the whirling pairs of dancers, the blonde heads intoxicated by the dance, resting on the striped Brandenburg chests. ${ }^{8}$

An anonymous author writing in a Polish magazine in the same period praised Wieniawski's works as 'well and carefully written', ${ }^{79}$ and perfunctorily characterised some of them: 'The Idyll makes the most graceful impression. The Ballade's theme is very well-conceived; Evocation seems a bit highfaluting. ${ }^{\text {'o }}$ Such mixed opinions seem to indicate the author's lack of bias. At that time, the death of Wieniawski's mother briefly interrupted his work as a composer and concert pianist.

On 10 April 1885 Wieniawski played two pieces from the aforementioned Opus 39. Kleczyński commented: 'Jeux de fées was beautifully performed', ${ }^{{ }_{1}}$ but 'Elegie orientale did not appeal to the audience. ${ }^{32} \mathrm{He}$ dedicated much more attention to the Piano Concerto in G minor Op. 20, which closed the concert programme. Its 'first movement, though with a touch of salon pomposity, is graceful and noble. ${ }^{8_{3}}$ The reviewer's opinion about the rest of the Concerto is less favourable. He comes close to rejecting the musical concept of the work, since 'we must not agree to a $2 / 2$ time, and especially the Finale, in whose style there is some inherent old-fashioned, anachronistic quality. ${ }^{34}$ Kleczyński

76 [N.N.], 'Nouvelles diverses', Le Guide Musical, 43 (1884), 349.

77 [N.N.], 'Nouvelles diverses', Le Guide Musical, 43 (1884), 349.

78 [N.N.], 'Petite chronique', L'Art Moderne, 43 (1884), 349.

79 [N.N.], 'Nowości Muzyczne', Echo Muzyczne i Teatralne, 56 (1884), 576.

so [N.N.], 'Nowości Muzyczne', Echo Muzyczne i Teatralne, 56 (1884), 576.

81 J. Kleczyński, 'Koncert Józefa Wieniawskiego', Echo Muzyczne, Teatralne i Artystyczne, 81 (1885), 158.

82 Kleczyński, 'Koncert Józefa Wieniawskiego', 158.

${ }_{83}$ Kleczyński, 'Koncert Józefa Wieniawskiego', 158.

${ }^{84}$ Kleczyński, 'Koncert Józefa Wieniawskiego', 158. 
clearly valued the composer's later works more highly. In October, he wrote in the same magazine: 'Józef Wieniawski has published a $P i$ ano Trio (Op. 40), which we still do not know. ${ }^{95}$ In late October the pianist 'completed a brilliant Fantaisie for two pianos, which will be performed by himself and Mr Artur de Greef during the concert on 19 December. ${ }^{36}$ Similar information appeared in the Dutch music journal Caecilia, which proves the new piece also attracted interest abroad: 'Mr Józef Wieniawski has just completed his Fantaisie for two pianos, which he will play with Mr Arthur de Greef during a concert held on 19 December at Le Grand Harmonie.. ${ }^{87}$

In the vocal part of the same concert, Anna Gregoir sang two of Wieniawski's songs, Si vous n'avez rien a me dire No. 2 and Il m'aimait tant No. 4 from Op. $38 .^{88}$ The author of the press note did not comment on this performance.

Another venue in Brussels where Wieniawski gave performances just as frequently as at Le Grand Harmonie was the Palais des Beaux-Arts, where he appears in concert cycles to which he invited his friends-musicians. It was there that Wieniawski played his Piano Trio Op. 40 with Jenő Hubay (violin) and Joseph Jacob (cello) during the first of two planned concerts, held on 17 February. The following detailed review of this work was published:

We praise Mr Wieniawski's Trio, and in particular its movements I, II, and IV: The first of them, for its somewhat romantic bravado and its sound, which brings to mind Chopin and Liszt; the second, for the development of the inconspicuous theme, containing the melancholy of a popular Polish song, sometimes with elements of Grieg; and the fourth, most solemn and captivating, but also full of reminiscences, this time - of Wagner. ${ }^{89}$

Movement Three, Scherzo, met with a less favourable appraisal, since 'the development is missing, and the end is overly violent.90 The

85 A. Urbański, 'Korespondencye Echa', Echo Muzyczne, Teatralne i Artystyczne, 110 (1885), 428.

86 [N.N.], 'Province', Le Guide Musical, 49 (1885), 351.

${ }_{87}$ [N.N.], 'Nieuve uitgaven', Caecilia. Algemeen Muzikaal Tijdschrift van Nederland, 24 (1885), 327.

88 [N.N.], 'Petite chronique', L'Art Moderne, 1 (1886), 7.

89 [N.N.], 'Petite chronique', L'Art Moderne, 8 (1886), 61.

$9 \circ \quad$ [N.N.], 'Petite chronique', L'Art Moderne, 8 (1886), 61. 
composition was presented again on 2 March in Brussels, by the same trio of musicians. Two weeks later Kleczyński printed his detailed review of the work in a Polish-language magazine:

It is with genuine interest and involvement that we have picked up this new piece for piano, violin and cello. Having previously become acquainted with the same composer's sonatas for piano and violin as well as for piano and cello, we highly valued their texture and design. We criticised the former for its excessive length, while in the latter we found the more compact form more interesting, and the Andante - very charming. We therefore expected to find many merits in this Trio, but our hopes have been almost completely thwarted. The themes, apart from the idea in the Scherzo, are dry and ungraceful, the form - long-winded, and everything is crammed with artificial pomposity. The Adagio and the Scherzo may make some more impression if carefully performed, but on the whole - the composition appears to be a failure. ${ }^{91}$

The above-quoted reviews well exemplify the evident discrepancy between opinions about Wieniawski's output presented by Polish and foreign critics. While foreign press praised the Trio, the composer's friend from his Warsaw years dismissed it as a failure and a complete misconception. He praised the Scherzo, however, which the Belgian author did not like. That foreign reviewers assessed Wieniawski's output more favourably and their attitudes differed from those of Polish critics is confirmed by a note from April 1886, in which we read that 'the Schott brothers have published a very interesting Trio for piano, violin and cello by Józef Wieniawski. ${ }^{92}$

In the second half of 1886 the press mainly informed about the already mentioned Fantaisie Op. 42 for two pianos. Kleczyński was the first to comment this time, and he wrote in a more favourable vein, emphasising the form, which resembled that of 'a great prelude. ${ }^{93}$ He added that the composition 'will be a valuable contribution to the still rather meagre literature for two pianos. ${ }^{94}$ In this way, however, he overlooked other Polish composers who wrote for two pianos in

91 J. Kleczyński, 'Nowości muzyczne’, Echo Muzyczne, Teatralne i Artystyczne, 128 (1886), 110.

${ }_{92}$ [N.N.], Bibliographie musicale, L’Art Moderne, 14 (1886), 110.

93 J. Kleczyński, 'Nowości muzyczne', Echo Muzyczne, Teatralne i Artystyczne, 141 (1886), 240.

94 J. Kleczyński, 'Nowości muzyczne', Echo Muzyczne, Teatralne i Artystyczne, 141 (1886), 240. 
the same period; the number of such works by, among others, Henryk Pachulski and Maurycy Moszkowski, was not smaller than in other parts of Europe.

The early months of 1887 abounded in performances of Wieniawski's own works. The composer was in Paris, preparing for his concerts to be held at Salle Erard on 31 January, 7 and 14 February. 'The programmes will include, apart from classical and contemporary piano repertoire, also the following works by Mr Wieniawski: Trio for piano, violin and cello; Fantaisie for two pianos, Piéces Romantiques for solo piano, Ecstasy and other songs, as well as Guillaume le Taciturne. ${ }^{95}$ No press reports from these concerts are available, though. While Wieniawski was rehearsing before his successive concerts, a Brussels publisher was preparing his Fantaisie Op. 42 for print. Information about this publication was accompanied by the following opinion:

It is written with talent, with a fluent pen that can cope well with difficult polyphony, and handles it skilfully, assigning more or less equal autonomous parts to each instrument. [The composer] demonstrates a cavalryman's elegance and that sort of dandyism which is the trademark of Wieniawski's music. ${ }^{96}$

The composition garnered favourable reviews also in later years during successive performances, mostly with pianist Arthur de Greef. In the first half of 1887 , Wieniawski's Piano Trio Op. 40 was a regular highlight of his repertoire, presented in Paris and London. On 29 March, the composer 'played the Trio of his own composition at Salle Erard with Messrs Remy and Deslert'97. In May, Le Figaro informed that 'Mr Józef Wieniawski is soon going to London, where he will perform his own works. ${ }^{38}$ The pianist gave four concerts in the British capital, one of which was held on 16 June at St James's Hall. The local press described it as an interesting performance which attracted numerous local music lovers. Wieniawski played his Trio Op. 40 with Mrs Norman-Néruda and Mr Patti. ${ }^{99}$ More details can be found in Le Guide Musical, where the correspondent reported: 'We heard Trio Op. 40 composed by Mr Wieniawski, of which particularly the Andante

95 [N.N.], 'Petite chronique', L'Art Moderne, 2 (1887), 15.

$96 \quad$ [N.N.], 'Petite chronique', L'Art Moderne, 13 (1887), 102.

97 [N.N.], 'Nowości muzyczne’, Echo Muzyczne, Teatralne i Artystyczne, 183 (1886), 177.

$98 \quad$ [N.N.], Petites Nouvelles, Le Figaro, 140 (1887), 3.

$99 \quad$ [N.N.], Illustrated London News, 2514 (1887), 714. 
and the Finale received an applause. ${ }^{100}$ The composition thus appears to have met with acclaim.

The end of the same year 1887 brings several references to Wieniawski's music in the press. Echo Muzyczne, Teatralne i Artystyczne informed about a cycle of études he was working on at that time:

Józef Wieniawski is composing a collection of études for the practice of style and technique (virtuosite) in all the major and minor keys. The whole, intended for highly advanced performers, consists of twenty-four pieces, each of which is to be dedicated to one famous pianist, to the character of whose talent and artistic individuality the given piece indirectly refers. ${ }^{101}$

Following his concerts in the United Kingdom, the pianist travelled to the Netherlands. From December we have a note saying that 'Marcella Sembrich and Józef Wieniawski have just completed a tour of the Netherlands. ${ }^{102}$ This provided yet another opportunity to present the composer's own music. The critic adds: 'The two great artists have played a beautiful programme, [including] Wieniawski's Extase [Entzückung], in which both musicians are greeted everywhere with applause. ${ }^{103}$ The Polish press informed that 'the audience especially awarded Wieniawski's song Extase, which earned both him and the singer a warm applause. ${ }^{104}$ Another symphonic concert, this time featuring Wieniawski as a conductor, took place on Saturday 27 December in Liège. The programme included 'apart from Haydn's B major Symphony, also Guillaume le Taciturne by Józef Wieniawski'. ${ }^{105}$

The first half of 1888 offered Wieniawski few opportunities to present his own works, and the press did not discuss his music. In April the illustrated Warsaw weekly Kłosy printed the following brief note by an anonymous author:

100 [N.N.] 'Nouvelles diverses', Le Guide Musical, 26-27 (1887).

${ }_{101}$ [N.N.], 'Nowości muzyczne', Echo Muzyczne, Teatralne i Artystyczne, 218 (1887), 571.

102 [N.N.], Petites Nouvelles, Le Figaro, 349 (1887), 3.

103 [N.N.], 'Petites Nouvelles', Le Figaro, 349 (1887), 3.

104 [N.N.], 'Nowości muzyczne', Echo Muzyczne, Teatralne i Artystyczne, 222 (1887), 618.

105 [N.N.], 'Nouvelles diverses', Le Guide Musical, 52 (1887), 342. 
major works by Mr Wieniawski include: a piano concerto, a sonata for piano and violin and another one for piano and cello, a string quartet, a piano trio, and a concert overture. From among his salon pieces, those that have enjoyed the greatest acclaim are: his valse de concert, a romance, mazurkas, études, and recently his lovely song Extase. $^{106}$

The critic only listed what he believed to be the composer's most representative works, without submitting them to any detailed appraisal. A similarly brief note, printed in L'Art Moderne in November, concerned one of Wieniawski's annual concerts at Salle Erard, held on the sixteenth day of that month, during which the pianist, accompanied by his pupil Louisa Merck, played his Fantaisie Op. 42 for two pianos. ${ }^{107}$

It was only in the first quarter of 1891 that the Polish press announced the completion of Wieniawski's long-awaited cycle of études in all keys. Jan Kleczyński informed:

Józef Wieniawski's 24 Études de mécanisme et de style pour le piano dans tous les tons majeurs et mineurs en 4 cahiers, in three booklets, which we have here in front of your eyes. Admittedly, having read the enthusiastic review of these études printed about one-and-a-half years ago in Guide musicale, where they were hailed as a 'musical monument' - we expected something more. It is a sequence of well-written pieces which demonstrate their author's good knowledge of musical textures and make an overall pleasant impression for this reason. Like nearly all of Wieniawski's output, however, they are permeated by the stylistic qualities of the bygone age and we cannot engage more deeply with that music for this reason. Besides, the ideas are quite commonplace, their level of difficulty and effectiveness average. Only a few [of the études] stand out, namely, the fourth, the seventh, and the opening of the fourteenth (a fugue). ${ }^{108}$

As in the case of other compositions before, Kleczyński's criticism is rather harsh. In late May 1891, a British daily informed about a concert by Ignacy Jan Paderewski, planned for 2 June at St James's Hall. On this occasion Wieniawski conducted his Overture Dramatique 'Guillaume

106 [N.N.], 'Ruch Muzyczny', Kłosy, 1190 (1888), 225.

107 [N.N.], 'Petite chronique', L'Art Moderne, 47 (1888), 374.

108 J. Kleczyński, 'Nowości muzyczne', Echo Muzyczne, Teatralne i Artystyczne, 390 (1891), 166. 
de Taciturne', which proved a success. ${ }^{109}$ This was not the composer's only performance in London. During another concert on 26 June, he appeared as a soloist and chamber musician:

Programme: - Sonata for Piano and Violoncello, Op. 26. M. Wieniawski and M. Joseph Hollman. Pensée fugitive; 3me. Polonaise, Op. 27; Jeux de fées, Op. 39, No. 3; Berceuse, Op. 14, No. 2; Étude de Concert, Op. 33; Mazourka-Reverie, Op. 23, No. 7; 8me. Romance Sans Paroles, G major; Barcarolle, B-flat major; Sur l'Ocean (contemplation), 2me. Valse-caprice, Op. 30. M. Wieniawski. Fantaisie for two pianos, Op. 42, M. Wieniawski and M. Paderewski. The whole of the above compositions by Joseph Wieniawski [...]. ${ }^{110}$

This was already the pianist's sixth visit to Great Britain, but the first one during which the programmes of the individual concerts were dominated by his own music. In the late 1891, as in the previous years, the artist focused on appearances at Le Grand Harmonie. For 12 November we have information not only about him playing the Piano Concerto with an orchestra, but also, for the first time, about 'Mmes Matthysens and De Gre (soprano and alto) singing five duets Op. 47 composed by Wieniawski', ${ }^{111}$ which was most likely the premiere performance of this cycle.

As in the previous years, there followed a break in Wieniawski's performances of his own music, which lasted until the first half of 1893, when 'on 18 May his Suite Romantique will be performed at Salle Erard, under the composer's baton'. ${ }^{12}$ A week later the structure of this work was discussed in the same paper:

Mr Józef Wieniawski's Suite Romantique, which he will conduct during the concert this Thursday, consists of four movements: Evocation, Scherzo, Idylle, and Mazurka villageoise. ${ }^{113}$

In late November it was announced that 'Mr Józef Wieniawski has visited Leipzig after again after a longer absence, ${ }^{114}$ where, as on

109 [N.N.], Morning Post, 37 (1891), 1.

11 [N.N.], The St James's Gazette, 3443 (1891), 1.

11 [N.N.], 'Dur und Moll', Signale für die Musikalische Welt, 72 (1891), 140.

112 [N.N.], 'Petites Nouvelles', Le Figaro, 101 (1893), 3.

${ }_{113}$ [N.N.], 'Petites Nouvelles', Le Figaro, 135 (1893), 5.

${ }_{114}$ [N.N.], 'Dur und Moll', Signale für die Musikalische Welt, 67 (1893), 1059. 
the previous occasions, he appeared at that city's Gewandhaus. On 8 December 'Mr Wieniawski performed with an orchestra. The programme included his Piano Concerto in G minor Op. 20, with which we are well familiar. ${ }^{315} \mathrm{He}$ performed in Leipzig again in late February 1895, when

the pianist and composer, now residing in Brussels, also demonstrated the full range of his abilities, and drew a thunderous applause with his interpretation of the piano part in his Trio Op. 40, performed with Messrs Brill and Will.1.16

The reviewer added the following opinion:

The composition appears to combine coherent form with lightness and balanced treatment of the three instruments, thus testifying to the artist's mastery and maturity as a pianist and composer. ${ }^{117}$

French-language press wrote in a similar spirit: 'The composition did not surprise anyone with novel ideas or powerful emotions, but its nobility and formal development make it truly worthwhile. ${ }^{118}$ The concerts in Leipzig were just one stage in Wieniawski's tour of Germany, as L'Art Moderne reminded its readers, commenting on the composer's presentations of his own symphonic works:

[...] in Berlin Mr Wieniawski appeared at the Concerthaus with two orchestral concerts. The programme included three of his own major works: Symphony in D major, Suite Romantique for orchestra, and Concerto for piano with orchestral accompaniment. ${ }^{119}$

The concerts earned him another success:

Mr Wieniawski conducted the first two pieces himself and took part in the performance of the Concerto. He won a warm applause and was called back several times. ${ }^{120}$

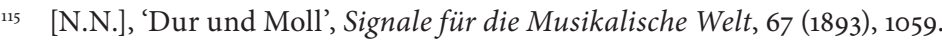


The composer spent May 1895 in Paris, where he played twice at Salle Pleyel. During the second of these concerts on 28 May 'he performed his own Violin Sonata with Mr G. Remmy. ${ }^{1212}$ A critic described the composition as follows: 'It is an improvised piece which has won us over to freer forms. ${ }^{122}$ Wieniawski's other pieces performed as a complement to the programme were: 'the Polonaise triomphale, Octave Étude, and Jeux de fees, which we had already heard before. ${ }^{123}$

In the first half of 1896, the pianist performed in Warsaw, where 'he had arrived with Władysław Żeleński on 15 April. ${ }^{124}$ Several months after the Paris concert, Wieniawski again presented his own music, appearing at the Ball Chambers [of the Grand Theatre] with an orchestra in two pieces. A critic wrote: "In Movement One of his Piano Concerto in $G$ minor, J. Wieniawski reminds us that he is an eminent virtuoso, but also capable of exploring the world of composition. ${ }^{125}$ The other work performed on that occasion was Suite Romantique, which invited the following commentary:

\section{Listen to the Pastoral Mazur from the orchestral Suite Romantique, a composition vibrating with the fullness of rhythm, wit and healthy humour, and you will see that he [Wieniawski] is a proper fruit of our soil, which he has enriched with learning, experience, and the progress of an artist who does not rest on his laurels but persistently pushes forward. And indeed, both the Mazur and the Evocation tes- tify to the genuine strength of his talent. When are we going to hear the whole of this cycle? $?^{126}$}

Despite such favourable reviews, the composition was never performed in Warsaw again. This proved to be the last symphonic concert played by Wieniawski in Congress Poland. He visited Warsaw again with a chamber music concert held on 11 March 1897. The Lublin-based cellist Michał Biernacki informs us that 'we have become acquainted with his Trio, Fantaisie for two pianos, and three vocal duets, ${ }^{127}$ and characterises these works:

121 [N.N.], 'Soirees et concerts', Le Ménestrel, 19 (1895), 152.

${ }_{122}$ [N.N.], 'Nouvelles diverses', Le Guide Musical, 23-24 (1895), 519.

${ }_{123}$ [N.N.], 'Nouvelles diverses', Le Guide Musical, 23-24 (1895), 519.

${ }_{124}$ [N.N.], Kurier Warszawski, 105 (1896), 3.

125 [N.N.], Kurier Warszawski, 109 (1896), 4.

126 [N.N.], Kurier Warszawski, 109 (1896), 4.

${ }_{127}$ M. Biernacki, 'Ruch Muzyczny', Echo Muzyczne, Teatralne i Artystyczne, 11 (1897). 
The Trio thus sounds splendid, especially when performed by its composer, Barcewicz, and Cink. In the Fantaisie Wieniawski indeed demonstrates enough fantasy and ideas to avoid the stereotype - that is, variations hitherto thought inevitable in pieces for two pianos in the presentation of his subtle and romantic main theme, which he does in an engaging way, with logical development, filling the work's framework with those ideas and enriching them with virtuosic effects. Both the soloist and his excellent partner, Ms Jankowska, carried out this difficult though pleasant task to perfection. Three two-part songs depart from Wieniawski's prevailing lofty style: Wake Up, Caliph Omar, and May Song, selected from a published cycle of six and performed by Ms Róża Rapacka (a light melodic soprano) and Ms Vieweger (a beautiful and graceful alto). Words by Goethe and Bodenstedt have been set to the graceful melody of the soprano, usually singing along with the alto, except for the second, most profound song, in which each of the two voices appears separately. The third song is a lesser form (with identical stanzas and ritornelli) which brings a true 'breath of spring'. This is why it was best liked and played as an encore. The value of all these duets is enhanced by the refined piano part, either accompanying the voices or presenting autonomous lines of thought. ${ }^{128}$

Biernacki, a member of Lublin Cathedral ensemble and an artist associated with Warsaw Music Society, conveyed, unlike Kleczyński, a favourable view of Wieniawski's output. Several weeks later, on 8, 15, and 22 April, the pianist gave three performances at the Parisian Salle Pleyel. ${ }^{129}$ It was announced that 'during the last concert Mr Wieniawski will present his own vocal and instrumental compositions ${ }^{\prime}{ }^{130}$ that is, most likely a programme similar to that performed in Warsaw, but the information is imprecise. From a later note we learn that on 8 April 'one of the works to be played during the concert is Mr Wieniawski's Symphony Op. 49, under the composer's baton.' ${ }^{131}$ There is no report on the concert held on 15 April.

In May 1898 a prestigious music magazine informed about a newly composed cycle (4 Klavierstücke Op. 51) comprising four pieces: Impromptu, Étude, Tristesse, and Valse. According to the critic,

128 M. Biernacki, 'Ruch Muzyczny', Echo Muzyczne, Teatralne i Artystyczne, 11 (1897).

${ }_{130} \quad$ [N.N.], 'Courrier de la semaine', Le Monde Artiste, 13 (1897), 206.

${ }_{131}$ [N.N.], 'Petite chronique', L’Art Moderne, 13 (1897), 103. 
the Impromptu is maintained, musically speaking, in a very subtle mood, with select harmonies. It very felicitously contrasts with the effectively brought out, contemplative first motif ${ }^{132}$.

The author further comments on the Étude that follows, which fulfils very well the role of an intermezzo, with the moving sixteenth section, a kind of perpetuum mobile. The piece, 'in the composer's spirit, in the liveliest time, performed with supple and relaxed fingers, well reflects its author's mastery. ${ }^{{ }_{133}}$ The reviewer wrote about the remaining two pieces in a similar vein. ${ }^{134}$ Similar information was printed in November 1898 in the French press, where each of the four compositions was analysed in considerable detail. The author concludes: 'These are four very well-written piano pieces, each successfully trimmed and suited to its title; each full of spicy harmonic surprises. ${ }^{{ }^{135}}$

Towards the end of the same year at Le Grand Harmonie in Brussels, the audience had the opportunity to listen to the Cello Sonata Op. 26 'performed by Messrs Józef Hollman and Józef Wieniawski' ${ }^{136}$ one of the most popular duos of the Brussels classical music scene in that period.

In May 1899, the composer visited London again, with a cycle of concerts at St. James's Hall. The one held on 11 May consisted of a solo and a chamber music part.

Several of Mr Joseph Wieniawski's compositions had places in the scheme, the first of these submitted being his String Quartet in A minor, which was admirably handled by Messrs. Theodore Werner, Haydn Inwards, Hobday, and Whitehouse. ${ }^{137}$.

The composition met with the following reception from the British reviewer:

This agreeable work contains an opening movement for the most part strenuous in character and forceful in expression, to which succeeds an Andante cantabile, a decidedly pleasing section, exhibiting

\footnotetext{
${ }_{132}$ 'Dur und Moll', Signale für die Musikalische Welt, 33 (1897), 513.

${ }_{133}$ 'Dur und Moll', Signale für die Musikalische Welt, 33 (1897), 513.

${ }_{134}$ 'Dur und Moll', Signale für die Musikalische Welt, 33 (1897), 513-514.

${ }_{135}$ [N.N.], 'Chronique étrangère', Revue Musicale Sainte Cécile, 3 (1898), 21.

${ }_{136}$ [N.N.], 'Nouvelles diverses', Le Guide Musical, 48 (1898), 906.

${ }_{137}$ [N.N.], The Daily Telegraph, 13 (1899), 1.
} 
quite a number of genuinely melodious and graceful passages. The Scherzo, though ingenious, is scarcely as interesting or effective as either of the earlier movements, but the Finale, which runs its course in animated fashion, is tuneful and engaging, bringing the work to a pleasing conclusion. ${ }^{138}$

This was the first such detailed appraisal of String Quartet Op. 32. In September we read about a concert in the Hague, where 'we shall hear Mr Józef Wieniawski's Overture, ${ }^{139}$ but no further details are given. Towards the end of the same year, the pianist played a series of concerts at the Maison d'Art, where on 14 November he performed, jointly with Hollman, his own Cello Sonata Op. 26:

This charming piece, whose lively and original themes are developed with a sense of humour, and in which [the composer's] expertise is evident in every successive measure - is an admirable work which met with applause after each of its movements. ${ }^{140}$

This opinion is, again, at odds with that of Jan Kleczyński, quoted above.

Several months later, on 5 April 1900 at Le Grand Harmonie, Wieniawski presented himself again as a composer of symphonic music. Though he led a busy concert life throughout that period, it is only in 1903 that we hear more about his own music. In early February, Le Guide Musical informed about another concert at Le Grand Harmonie, whose programme included Beethoven and Chopin, as well as 'two of his [Wieniawski's] compositions, which were highly acclaimed: Reverie and Romance No. $4^{3} .^{141}$ With time, though still equally active as a pianist, Wieniawski performed his own music much less frequently.

One such a performance took place on 5 May 1904 at Salle Pleyel, where 'during the second concert, Mr Wieniawski will present exclusively his own compositions: Polonaise triomphale, Valse-caprice, Sonate pour le piano, and others. ${ }^{1{ }^{142}}$ For a symphonic concert featuring Wieniawski's music, the audience had to wait until 1908. This presentation, on 9 April in Berlin, proved to be one of the composer's last. It was

${ }_{138}$ [N.N.], The Daily Telegraph, 13 (1899), 1.

139 [N.N.], 'Nouvelles diverses', Le Guide Musical, 37 (1899), 661.

140 [N.N.], 'Nouvelles diverses', Le Guide Musical, 45 (1899), 849.

${ }_{141}$ [N.N.], 'Nouvelles diverses', Le Guide Musical, 6 (1903), 125.

${ }_{142}$ [N.N.], 'Petites Nouvelles', Le Figaro, 100 (1904), 4. 
announced as early as January: 'The programme includes Symphony in D major Op. 49 and Piano Concerto in G minor Op. 20, composed by himself.'.143 Several weeks earlier the composer had presented the same programme at Le Grand Harmonie, where on 19 March 'Mr Wieniawski led the orchestra in his Symphony Op. 49 and Piano Concerto Op. $20^{1144}$ (no further details were provided).

The year 1908 also brought some quite detailed analyses of selected works, which offer evidence that interest in his music was growing. Der Klavier-Lehrer reported in December that 'Józef Wieniawski has again revised and published one of his youthful pieces: Piano Sonata in B minor Op. 22. ${ }^{145}$ The author concludes his quite extensive analysis as follows:

Changing times and tastes have no doubt contributed to the fact that Wieniawski's B minor Sonata seems so faded and trifling to us today. One may easily admit that, given a delicate delivery, it still continues to offer very decent, light music, and can be recommended from this perspective. ${ }^{146}$

With the passage of time, Wieniawski's music was undergoing stylistic and formal transformations, which were observed by another German critic discussing in Musikästhetische Betrachtungen the composer's selected works (Valse de concert Op. 3, Berceuse Op. 14 No. 2, Polonaise Op. 27, Ballade Op. 31, Étude de concert Op. 33, and Étude de concert Op. 36) from different periods of his activity. ${ }^{147}$ Another review of the Piano Sonata Op. 22, printed in mid-1908, struck, as we shall see, a different note from the one quoted above:

The sonata cycle does not seem to be this composer's strongest point. In Allegro con brio the two outermost statements are strong and daring, but the middle is not very refined, and the architecture of the whole - of low calibre. In terms of form, the composer fails us altogether. ${ }^{148}$

143 [N.N.], 'Soirees et concerts', Le Ménestrel, 2 (1908), 13.

144 [N.N.], 'Soirees et concerts', Le Ménestrel, 11 (1908), 87.

145 [N.N.], 'Joseph Wieniawski', Der Klavier-Lehrer, 24 (1908), 9.

146 [N.N.], 'Joseph Wieniawski', Der Klavier-Lehrer, 24 (1908), 10.

147 N., 'Joseph Wieniawski', Musikästhetische Betrachtungen, 4 (1909), 233-235.

${ }_{148}$ A. Leitzmann, 'Joseph Wieniawski Sonate pour Piano op. 22', Die Musik, 4 (1909), 235. 
Similar criticism of Wieniawski's formal constructions had already been voiced before by Kleczyński with reference to the Trio and the Cello Sonata. This, however, did not discourage Wieniawski from composing more music. In mid-March he visited Leipzig again after a long break and performed there to mark the birthday of Johann Sebastian Bach. A reviewer wrote:

\section{Mr Wieniawski proved his mastery as a composer with works he performed himself: Etude de concert in G major Op. 33, Barcarolle in B-flat major Op. 29, Valse-caprice in A major Op. 46, and Sonata in $B$ minor. ${ }^{149}$}

The latter piece, however, met with similar criticism as in the review quoted above. This time, Sonata in B minor is described as 'not an originally treated form, but a collection of passages and figurations, grouped especially in Movement One, and derivative of Schubert. ${ }^{150}$ Such an opinion may have been provoked by the composer limiting himself to a tripartite form.

Late in 1910, as in the previous seasons, Wieniawski returned to Le Grand Harmonie with another series of concerts, the first of which was held on Sunday 10 November, when 'Mmes Couveiller and Kalker, Mr Flament's pupils, pleasantly interpreted two-part songs by Mr Józef Wieniawski. ${ }^{351}$ The cycle of duets Op. 47 was the crowning achievement of Wieniawski's song writing. The concert series continued at the Nouvelle Salle (11 Rue Ernest Allard, Brussels) where 'the programme will include Brahms' String Quartet as well as the first performance of a String Quartet by Józef Wieniawski. ${ }^{152}$ A revised version of this piece, with changes mainly in texture and tonal structure, was presented during the concert on 11 May. The composer removed the Scherzo, leaving only three movements. On that latter occasion, however, the piece which 'inspired a special euphoria was the Piano Sonata in B minor Op. 22. ${ }^{153}$

During the second concert, held on 31 May, Wieniawski appeared with a group of friends mainly in chamber repertoire, but also played

\footnotetext{
149 [N.N.], 'Leipzig', Musikalisches Wochenblatt, 13 (1910), 7.

150 [N.N.], 'Leipzig', 7.

${ }_{151}$ [N.N.], 'Nouvelles diverses', Le Guide Musical, 46 (1910), 740.

152 [N.N.], 'Nouvelles diverses', Le Guide Musical, 7 (1911), 134.

153 [N.N.], 'Nouvelles diverses', Le Guide Musical, 22-23 (1911), 415.
} 
several solo numbers. Reflecting on this concert in a French magazine, Charles Malherbe wrote about the piano works:

Sonata in B minor Op. 22, Ballade Op. 31, and Deuxieme Étude de Concert Op. 33 testify to extraordinary sensitivity, an amazing flourishing of ideas, and immaculate harmony. ${ }^{154}$

which reflects the composer's merits. The chamber music was described in a similarly positive manner:

Mr Wieniawski presented his String Quartet Op. 32, Piano Trio Op. 40, and Cello Sonata Op. 26. The quartet was brilliantly and gracefully interpreted by Messrs André le Mayer and César Espéjo (violins), Charles Meyeux (viola), and Andre Bernaldel (cello). Owing to Mr Hollman, the Cello Sonata proved the most impressive point of the programme. The Trio may be considered as a miracle, one of its kind. ${ }^{155}$

Le Guide Musical wrote in a similar vein ${ }^{156}$ in what proved to be the last press account of a concert given by Wieniawski. Little did the composer know that he was entering the stage for the last time in his life. He played some of the most representative works from his output, which may be interpreted as his artistic testament.

As I mentioned in the introduction, the life and work of Józef Wieniawski have not been the subject of any detailed contemporary analyses. In his lifetime, he was one of those Polish artists who enjoyed considerable popularity and won acclaim in the most prestigious cultural hubs of the then Europe. This is amply documented by articles from Polish and foreign press which have been studied for the needs of this paper. The press printed not only reports from, or announcements of, concerts, but also in-depth analyses and critical reviews of Wieniawski's own music, which was regularly present on concert stages at that time. My source analysis demonstrates that the music of the famous violinist's brother attracted much interest among both Polish and foreign critics, though it met with greatly varied reception.

154 [N.N.], 'Paris et départements', Le Ménestrel, 23 (1911), 182.

155 'Paris et départements', 182.

156 [N.N.], 'Salle Pleyel', Le Guide Musical, 26-27 (1911), 456. 


\section{Bibliography}

\section{References}

Delcroix, L., Joseph Wieniawski (J.-B. Katto: Bruxelles, 1908).

Rzepecki, K., 'Józef Wieniawski (1837-1912) - epoka, człowiek i dzieło. Studium historyczno-muzykologiczne', PhD dissertation (Repozytorium Instytucjonalne KUL: Lublin, 2019).

Wieniawski J., Cadenza pour le 3me Concerto pour le Piano de Beethoven

(Stanley Lucas: London, 1878).

\section{Press Articles and Notes}

[N.N.], 'Bibliographie musicale', L'Art Moderne, 14 (1886).

Biernacki, M., 'Ruch Muzyczny', Echo Muzyczne, Teatralne i Artystyczne, 11 (1897).

Botte, A., 'Koncert Józefa Wieniawskiego', Revue Gazette Musicale de Paris, 52 (1860).

Bylicki, F., 'Ze sceny koncertowej', Gazeta Lwowska, 13 (1881).

[N.N.], 'Chronique étrangère', Revue Gazette Musicale de Paris, 9 (1857).

[N.N.], 'Chronique étrangère', Revue Gazette Musicale de Paris, 19 (1860).

[N.N.], 'Chronique étrangère', Revue Musicale Sainte Cécile, 3 (1898).

[N.N.], 'Concerts Wieniawski', L’Art Moderne, 5 (1883).

[N.N.], 'Courrier de la semaine', Le Monde Artiste, 13 (1897).

Doroszenko, J., 'Wieści z kijowskich koncertów', Ruch Muzyczny, 12 (1859).

[N.N.], 'Dur und Moll', Signale für die Musikalische Welt, 38 (1861).

[N.N.], 'Dur und Moll', Signale für die Musikalische Welt, 18 (1863).

[N.N.], 'Dur und Moll', Signale für die Musikalische Welt, 42 (1863).

[N.N.], 'Dur und Moll', Signale für die Musikalische Welt, 72 (1891).

[N.N.], 'Dur und Moll', Signale für die Musikalische Welt, 67 (1893).

[N.N.], 'Dur und Moll', Signale für die Musikalische Welt, 17 (1895).

[N.N.], 'Dur und Moll', Signale für die Musikalische Welt, 33 (1897).

[N.N.], 'Echos des theatres', Le Gaulois, 888 (1882), 4.

[N.N.], 'Eingesandte Concert-Programme', Musikalisches Centralblatt, 18 (1882).

[N.N.], 'Eingesandte Concert-Programme', Musikalisches Centralblatt, 4 (1883).

E.K., 'Przegląd kompozycyj', Ruch Muzyczny, 7 (1857). 
[N.N.], Illustrated London News, 2514 (1887).

[N.N.], 'Gazeta Muzyczna', Ruch Muzyczny, 10 (1861).

[N.N.], 'Joseph Wieniawski', Der Klavier-Lehrer, 24 (1908).

[N.N.], 'Józef Wieniawski', Ruch Muzyczny, 7 (1858).

Ker, 'Grand Duo Polonais pour Violon et Piano concertant compose par les freres Henri et Joseph Wieniawski', Signale für die Musikalische Welt, 31 (1855).

Kleczyński, J., 'Ruch Muzyczny', Bluszcz, 51 (1868).

Kleczyński, J., 'Ruch Muzyczny', Bluszcz, 13 (1871).

Kleczyński, J., 'Ruch Muzyczny', Bluszcz, 18 (1871).

Kleczyński, J., 'Ruch Muzyczny', Bluszcz, 16 (1876).

Kleczyński, J., 'Nowości Muzyczne', Echo Muzyczne, Teatralne i Artystyczne, 128 (1886).

Kleczyński, J., 'Nowości Muzyczne', Echo Muzyczne, Teatralne i Artystyczne, 141 (1886).

Kleczyński, J., 'Nowości Muzyczne', Echo Muzyczne, Teatralne i Artystyczne, 390 (1891).

Kleczyński, J., 'Józef Wieniawski', Echo Muzyczne i Teatralne, 36 (1884).

Kleczyński, J., 'Koncert Józefa Wieniawskiego', Echo Muzyczne, Teatralne i Artystyczne, 81 (1885).

Kleczyński, J., 'Ze świata muzycznego', Tygodnik Ilustrowany, 57 (1869).

[N.N.], 'Nowości Muzyczne', Kłosy, 1190 (1888).

[N.N.], 'Koncert Pana Józefa Wieniawskiego', Ruch Muzyczny, 10 (1858).

[N.N.], 'Koncert Pana Jozefa Wieniawskiego w Resursie Kupieckiej', Ruch Muzyczny, 13 (1858).

[N.N.], 'Koncert pp. J. Wieniawskiego, Al. Reicharda i Ad. Hermana', Ruch Muzyczny, 51 (1858).

[N.N.], Kurier Warszawski, 207 (1876).

[N.N.], Kurier Warszawski, 219 (1876).

[N.N.], Kurier Warszawski, 211 (1877).

[N.N.], Kurier Warszawski, 218 (1877).

[N.N.], Kurier Warszawski, 290 (1878).

[N.N.], Kurier Warszawski, 105 (1896).

[N.N.], Kurier Warszawski, 109 (1896).

[N.N.], 'Le Journée', L’Europe, 917 (1882).

[N.N.], 'Leipzig', Musikalisches Wochenblatt, 13 (1910).

Leitzmann, A., 'Joseph Wieniawski Sonate pour Piano op. 22', Die Musik, 4 (1909). 
[N.N.], 'Les peintres belges au salon', L'Art Moderne, 25 (1884).

[N.N.], Morning Post, 37 (1891).

N., 'Joseph Wieniawski', Musikästhetische Betrachtungen, 4 (1909).

[N.N.], 'Nieuve uitgaven', Caecilia. Algemeen Muzikaal Tijdschrift van Nederland, 24 (1885).

[N.N.], 'Nouvelles', Revue Gazette Musicale de Paris, 53 (1860).

[N.N.], 'Nouvelles diverses', Le Guide Musical, 34-35 (1884).

[N.N.], 'Nouvelles diverses', Le Guide Musical, 37 (1884).

[N.N.], 'Nouvelles diverses', Le Guide Musical, 43 (1884).

[N.N.], 'Nouvelles diverses', Le Guide Musical, 26-27 (1887).

[N.N.], 'Nouvelles diverses', Le Guide Musical, 52 (1887).

[N.N.], 'Nouvelles diverses', Le Guide Musical, 15 (1895).

[N.N.], 'Nouvelles diverses', Le Guide Musical, 23-24 (1895).

[N.N.], 'Nouvelles diverses', Le Guide Musical, 48 (1898).

[N.N.], 'Nouvelles diverses', Le Guide Musical, 37 (1899).

[N.N.], 'Nouvelles diverses', Le Guide Musical, 45 (1899).

[N.N.], 'Nouvelles diverses', Le Guide Musical, 11 (1900).

[N.N.], 'Nouvelles diverses', Le Guide Musical, 6 (1903).

[N.N.], 'Nouvelles diverses', Le Guide Musical, 46 (1910).

[N.N.], 'Nouvelles diverses', Le Guide Musical, 7 (1911).

[N.N.], 'Nowości Muzyczne', Echo Muzyczne i Teatralne, 56 (1884).

[N.N.], 'Nowości Muzyczne', Echo Muzyczne, Teatralne i Artystyczne, 183 (1887).

[N.N.], 'Nowości Muzyczne', Echo Muzyczne, Teatralne i Artystyczne, 222 (1887).

[N.N.], 'Paris et départements', Le Ménestrel, 23 (1911).

[N.N.], 'Petite chronique', L’Art Moderne, 4 (1884).

[N.N.], 'Petite chronique', L'Art Moderne, 43 (1884).

[N.N.], 'Petite chronique', L'Art Moderne, 1 (1886).

[N.N.], 'Petite chronique', L'Art Moderne, 8 (1886).

[N.N.], 'Petite chronique', L’Art Moderne, 2 (1887).

[N.N.], 'Petite chronique', L'Art Moderne, 13 (1887).

[N.N.], 'Petite chronique', L'Art Moderne, 47 (1888).

[N.N.], 'Petite chronique', L'Art Moderne, 16 (1895).

[N.N.], 'Petite chronique', L'Art Moderne, 13 (1897).

[N.N.], 'Petites Nouvelles', Le Figaro, 140 (1887).

[N.N.], 'Petites Nouvelles', Le Figaro, 101 (1893).

[N.N.], 'Petites Nouvelles', Le Figaro, 135 (1893). 
[N.N.], 'Petites Nouvelles', Le Figaro, 100 (1904).

[N.N.], 'Province', Le Guide Musical, 49 (1885).

[N.N.], 'Przegląd Muzyczny', Ruch Muzyczny, 19 (1860).

[N.N.], 'Revue des theatres', Le Petit Journal, 7001 (1882).

[N.N.], 'Salle Pleyel', Le Guide Musical, 26-27 (1911).

[N.N.], 'Soirees et concerts', Le Ménestrel, 27 (1860).

[N.N.], 'Soirees et concerts', Le Ménestrel, 28 (1860).

[N.N.], 'Soirees et concerts', Le Ménestrel, 19 (1895).

[N.N.], 'Soirees et concerts', Le Ménestrel, 2 (1908).

[N.N.], 'Soirees et concerts', Le Ménestrel, 11 (1908).

[N.N.], The Daily Telegraph, 13 (1899).

[N.N.], The St James's Gazette, 3443 (1891).

[N.N.], 'Trzeci koncert p. Józefa Wieniawskiego', Ruch Muzyczny, 15 (1858).

Urbański, A., 'Korespondencye Echa', Echo Muzyczne, Teatralne i Artystyczne, 110 (1885). 